\title{
Improving the placement of food products of organic origin on the AP Vojvodina market
}

\author{
Jelena Končar \\ University of Novi Sad, Faculty of Economics in Subotica, Subotica, Serbia \\ Aleksandar Grubor \\ University of Novi Sad, Faculty of Economics in Subotica, Subotica, Serbia \\ Radenko Marić \\ University of Novi Sad, Faculty of Economics in Subotica, Subotica, Serbia
}

\begin{abstract}
The aim of this paper is to define suggestions and guidelines for improving the placement of food products of organic origin in the AP Vojvodina market. The main task is to identify and analyse indicators that the final consumers consider most important when purchasing food products of organic origin. The data was collected by field and electronic studies on a sample of 500 final consumers about their expectations, attitudes and habits in the purchase and consumption of organic food. Descriptive statistics was used for data processing, while multiple regression analysis was used to interpret results and test the established hypotheses. The results showed the existence of statistically significant correlations between different indicators, such as: quality label, origin of the product, composition of raw materials, freshness, price, taste, place of sale and packaging and consumers' decision to purchase an organic food product. The results of the research will serve as a basis for the creation of a regression model for the successful placement of food products of organic origin in the AP Vojvodina market. The practical significance of the research is reflected in the fact that it will indicate to the supply chain managers the indicators that need to be optimized to ensure more efficient placement of organic products on the national market. Suggestions and recommendations for future research are provided in the paper.
\end{abstract}

\section{Keywords}

Food products of organic origin, quality, consumer's expectations, product origin, supply chains.

\section{Introduction}

In previous studies, the authors point to an increasing share of organic food products in the consumer basket, which in the EU market ranges from $4.5 \%$ in the UK to $14 \%$ in Denmark (Wier, Jensen, Andersen, \& Millock, 2008). Changes are also evident in the advertising activities, where an increasing significance on the global market is attributed to organic products. According to the results of a global study conducted in 2016, which included an analysis of 128 world journals, out of 579 advertisements published in these journals, 178 or $31 \%$ of them referred to organic food products (Gebhardt \& Heinz, 2018). Data show that world demand for organic food products grows at an annual rate of $20 \%$, while it is estimated that the retail sales of such products annually exceed $\$$ 100 billion (US\$), with the trend that $93 \%$ of global consumers expect placement of exclusively those products that are produced according to the highest ecological standards (Arsi, Donoghue, Venkitanarayanan, \& Donoghue, 2019; Hjelmar, 2011). In line with this trend in the global market, consumers' expectations are growing (Popesku, 2018) as well, and therefore they consider organic food products to be better in taste, more natural, healthier and safer than conventional alternatives 
for consumers and the environment (Kataria, Krishna, Tyagi, \& Vashishat, 2019).

Unlike in developed countries, insufficient attention is paid to organic production, placement and consumption in our market. The data show that in the Republic of Serbia the share of organic land in the total land is only $0.44 \%$ or 15,000 ha with a total of 2,000 agricultural producers and processors (Gulan, 2017). Compared to EU countries where the placement of organic food products grows at an annual rate of $10-15 \%$ (Martić Kuran \& Mihić, 2014), this growth rate in Serbia is estimated at only 2 to $3 \%$ (Končar et al, 2018).

However, the key provisions of Serbia 2020 the Concept of Development of the Republic of Serbia until 2020 anticipate a significant redesign of the role of traditional food products of organic origin as a holder of rural development and the overall economic potential of the Republic of Serbia (Stojanović \& Ognjanov, 2012). In this context, this implies directing state subsidies to improving the placement of organic products, financial support for the development of organic production, allocation of tax incentives for organic producers, control and certification of organic food, etc. In addition, certainly the most important factor is the views of local consumers about their readiness to dominantly buy food products of organic origin (Grubor \& Đokić, 2015).

Bearing in mind the mentioned aspects, the subject of this paper is the research of consumers' expectations of organic products on the market of AP Vojvodina. The aim of the paper is to define the significance of the indicators that final consumers consider most important when purchasing food products of organic origin. The obtained results of the research will serve as the basis for the creation of a regression model with proposals and guidelines for improvement of the placement of food products of organic origin on the market of AP Vojvodina.

The paper consists of the following sections. The introduction is followed by the Theoretical background of the research that pointed to the importance of supplying organic products and defined indicators that influence the placement of food products of organic origin. Based on the literature review, basic research hypotheses are established. The method, sample and variables of the research are presented in the chapter Methodology. The next chapter - Results, presents the results of the tests carried out. The chapter Discussion, defines the regression model, summarizes the most important results of the conducted research and provides the guidelines for the improvement of the placement of food products of organic origin. The last chapter brings together proposals and guidelines for future research and points to the observed shortcomings of the conducted research.

\section{Theoretical background and research hypothesis}

Organic food products represent a significant segment of the entire supply chain. Research in the global market (Batte, Hooker, Haab, \& Beaverson, 2007) shows that organic products must first be clearly differentiated into: $100 \%$ organic products, organic products (at least 95\% organic), products produced with organic ingredients (at least $70 \%$ ) and products with some organic ingredients (contain up to $70 \%$ of organic substances). Only the first three categories can use the word organic in their name. These are products obtained through a system of organic farming and production, without the use of chemicals, pesticides, additives, emulsifiers, artificial constituents, raw materials and fertilizers (Charter, 2001).

Consumers attach greater importance to these products especially in the food segment. The results of numerous studies confirm that the growth rate of organic foodstuffs by far exceeds the overall growth rate of the food market. In the period from 2002 to 2011, the overall growth rate of the food market was $33 \%$ compared to $238 \%$ of the growth rate of food products of organic origin (Koklic, Golob, Podnar, \& Zabkar, 2019). Consumers consider fruits and vegetables, milk and dairy products and cereals as the most important organic products, while the organic meat market has seen the highest trend of growth in recent years (Nguyen, Nguyen, Nguyen, Lobo, \& Vu, 2019).

Retail chains dominate in the placement of organic food products in the EU market by achieving 16-25\% (Malta, Poland, Spain, Italy) up to $80-90 \%$ (Romania, Bulgaria, Denmark, Finland, Norway) when it comes to the sales of organic food (Brčić-Stipčević, Petljak, \& Guszak, 2011). As a result of such developments, final consumers show a tendency towards proven safety, quality, composition and origin of food products. Research on the global market confirms the direct correlation between consumer safety in the quality and composition of organic products and the efficiency of placements (Wong \& Tzeng, 2019; Končar, Marić, \& Vukmirović, 2018; Truong, Yap, \& Ineson, 2012). 
In the global market, the most important indicators that influence the consumption of organic products are the health of consumers and producers (Truong et al, 2012), ecological reasons (Pearson, Henryks, Sultan, \& Anisimova, 2013), sustainability (Jurjević, Bogićević, Đokić, \& Matkovski, 2019), safety (Truong et al, 2012), ethical motives (Honkanen, Verplanken, \& Olsen, 2006), cognitive quality knowledge (Sponte, 2018), etc. Similarly to these results, on the local market, and especially in the AP Vojvodina market, the conducted studies pointed to the following indicators that consumers value as crucial in the selection and purchase of food products of organic origin. The following is emphasized: geographical origin labels (Stojanović \& Ognjanov, 2012), quality labels (Končar, Grubor, Marić, Vukmirović, \& Đokić, 2019), trust in composition and quality (Grubor \& Đokić, 2015), health safety (Prodanović, Kuzman, Jovović, \& Ozegović, 2017; Vlahović, Puškarić, \& Jeločnik, 2011), taste (Vehapi, 2015), brand (Kocić, Marinković, \& Alimpic, 2016), etc. The most common reasons that discourage consumers from purchasing organic products in our market are as follows: price $(30 \%)$, distrust in quality labels (22), poor supply $(21 \%)$, unavailability $(20 \%)$, etc. (Vehapi, 2015).

End-users show increasing interest in all aspects of quality, safety and trust in organic food ingredients. If the participants in the supply chain, i.e. the producers (processors), farmers and trade companies are trying to improve the placement of these products, the supply chain management needs to focus in particular on the following indicators: quality label, product origin, composition of raw materials, freshness, price, taste, place of sale and packaging.

Quality label refers to the certification and standardization of organic products. It is crucial to determine if and to what extent consumers pay attention and trust these labels in our market.

Product origin relates to the geographical origin, i.e. place of food production, whether it is domestic or foreign producers and whether the origin affects the differences in the expectations of the final consumers.

Composition of raw materials includes the content of pure organic substances of a food product without additives such as emulsifiers (E102, E103, E104, etc.), GMOs, additives, pesticides, chemicals, artificial colours, etc.

Freshness, as a product quality indicator, is a characteristic of the product's durability, indicates some changes in deterioration (meat and meat products) or rotting of the product (fruits, vegetables), indicates the presence of foreign matter in a product, damage to the packaging, etc.

Price, as a placement indicator implies the price at which food products are placed in retail facilities. It is usually $30 \%$ higher than the price of conventional food products, as a consequence of: small amount of placement, expensive technology, complex and costly certification procedure, expensive packaging, etc.

Taste can be a significant motive for the purchase of food products of organic origin. As an indicator, taste is especially pronounced in fruits, vegetables, meat and meat products, bread and pastry, where consumers consider organic foods more tasty than conventional food products (Kihlberg \& Risvik, 2007).

Place of sale refers to the question of whether a place (selling facility) where a product is purchased can be a predictor of quality and consumers' certainty in the organic composition of food products. These can be: retail facilities, green markets, or purchasing organic food directly from a manufacturer (processor).

Packaging relates to the improvement of the ecological status of packaging. For organic product groups, this implies a good knowledge of their functional characteristics and the ecological status of packaging materials and waste, which means that the packaging must be made of environmentally friendly raw materials and biodegradable or recyclable materials, using renewable resources and energy sources.

The subject of the research set up in this way is operationalized through the following eight research hypotheses:

$\mathbf{H}_{\mathbf{1}}$ - Quality label is an indicator that has a statistically significant impact on consumers' decision when purchasing food products of organic origin.

$\mathbf{H}_{\mathbf{2}}$ - Product origin is an indicator that has a statistically significant impact on consumers' decision when purchasing food products of organic origin.

$\mathbf{H}_{3}$ - Composition of raw materials is an indicator that has a statistically significant impact on consumers' decision when purchasing food products of organic origin.

$\mathbf{H}_{4}$ - Freshness is an indicator that has a statistically significant impact on consumers' decision when purchasing food products of organic origin. 
$\mathbf{H}_{5}$ - Price is an indicator that has a statistically significant impact on consumers' decision when purchasing food products of organic origin.

$\mathbf{H}_{6}-$ Taste is an indicator that has a statistically significant impact on consumers' decision when purchasing food products of organic origin.

$\mathbf{H}_{7}$ - Place of sale is an indicator that has a statistically significant impact on consumers' decision when purchasing food products of organic origin.

$\mathbf{H}_{\mathbf{8}}$ - Packaging is an indicator that has a statistically significant impact on consumers' decision when purchasing food products of organic origin.

The most important results of the research, comments related to testing of hypotheses and suggestions for improving the placement of food products of organic origin are presented below.

\section{Methodology}

\subsection{Variables}

The study included several variables for confirming or rejecting these hypotheses. These are: independent variable of interval type of measurement and dependent variable. The independent variable of the interval type of measurement includes the assessment (ranking) of the significance of each of the offered indicators to the final consumers' expectation when selecting and purchasing organic food. The individual contribution of each indicator is ranked on the basis of the Likert scale (1-5 ranks). The dependent variable is the expectation, i.e. consumers' decision on the selection and purchase of food products of organic origin, i.e. to what extent indicators, such as: quality label, product origin, composition of raw materials, freshness, price, taste, place of sale and packaging meet their expectations and affect the decision to purchase food products of organic origin.

\subsection{Research sample}

The research was carried out on a sample of 500 final consumers from the territory of AP Vojvodina. The obtained data are the result of the research within the short-term projects of special interest for sustainable development in AP Vojvodina in 2018, based on a research project: "Study on the sustainability of domestic manufacturers and trading companies in the placement of food and organic products in the AP Vojvodina market". The study was carried out in the period September 2018 - April 2019. The sample was dominated by female consumers $(\mathrm{m}=172$ or $34.4 \% ; \mathrm{f}=328$ or $65.6 \%)$, due to their greater willingness to participate in the research. The highest share of respondents in the sample had higher education ( $\mathrm{n}=295$ or $59 \%$ ). However, the sample is uniform in terms of respondents' age, place of residence (urban/rural) and household income.

In order to determine the reliability and validity of the used measurement scales for each of the tested indicators, the Cronbach Alpha coefficient was used (Table 1).

Table 1 Values of Cronbach's coefficient alpha for scale reliability

\begin{tabular}{|c|c|}
\hline Indicators & Cronbach's alpha \\
\hline Quality label & .742 \\
\hline Product origin & .873 \\
\hline Composition of raw materials & .901 \\
\hline Freshness & .718 \\
\hline Price & .866 \\
\hline Taste & .849 \\
\hline Place of sale & .773 \\
\hline Packaging & .842 \\
\hline For all items & .897 \\
\hline
\end{tabular}

The value of the alpha coefficient, which for all indicators is closer to 1 than 0 , indicates that the applied scales have an excellent level of reliability, i.e. they are valid for measuring the attitudes and opinions of final consumers.

\subsection{Research procedure}

The research was carried out by field studies and electronically via an e-questionnaire that was sent to final consumers from the base of trading companies. The average filling time of the questionnaire was from 10 to 15 minutes. Questionnaires were sent to final consumers until there were 500 successfully completed questionnaires. A total of 643 questionnaires were distributed (response rate, $\mathrm{n}=77.76 \%$ ).

The data were sorted and processed with the SPSS 20 statistical package. Respondents' answers were interpreted and analysed through descriptive statistics. Average values, as well as deviations for each indicator, are presented. Correlation between the indicators is determined by the Correlation matrix, while the accuracy of the set hypotheses is tested based on multiple regression analysis. 


\section{Results}

The following table (Table 2) shows the average ranking of each of these indicators, i.e. the degree of agreement of the final consumers with the assertion that the analysed indicators significantly influence their decision to purchase food products of organic origin.

Table 2 Results of individual indicator ranking

\begin{tabular}{c|l|c}
\hline No. & \multicolumn{1}{|c}{ Indicators } & Significance rank \\
\hline 1 & Quality label & 4.32 \\
\hline 2 & Product origin & 3.94 \\
\hline 3 & Composition of raw materials & 4.22 \\
\hline 4 & Freshness & 3.14 \\
\hline 5 & Price & 4.12 \\
\hline 6 & Taste & 2.85 \\
\hline 7 & Sale of purchase & 3.71 \\
\hline 8 & Packaging & 2.68 \\
\hline 9 & For all items & 4.08 \\
\hline
\end{tabular}

The attached table shows that final consumers' decision to purchase organic food products in the AP Vojvodina market is most significantly affected by the indicator of quality label and composition of raw materials. Somewhat less significance respondents attach to price, product origin and place of sale, while the lowest degree of agreement is indicated for the indicators: freshness, taste and packaging of organic food. In addition to these descriptive indicators, the following table (Table 3) presents descriptive statistics by individual indicators.

Table 3 Descriptive statistics for the analysed indicators

\begin{tabular}{l|c|c|c|c}
\hline \multicolumn{1}{c|}{ Indicators } & Min. & Max. & Mean & $\begin{array}{c}\text { St. } \\
\text { deviation }\end{array}$ \\
\hline Quality label & 2.33 & 5.00 & 4.3280 & 1.17874 \\
\hline $\begin{array}{l}\text { Product origin } \\
\text { Composition of raw } \\
\text { materials }\end{array}$ & 1.67 & 4.67 & 3.9492 & .85697 \\
\hline Freshness & 1.67 & 4.67 & 4.2203 & .97461 \\
\hline Price & 1.00 & 4.00 & 3.1499 & 1.24192 \\
\hline Taste & 1.00 & 3.97 & 4.1202 & 1.17582 \\
\hline Place of sale & 1.33 & 4.33 & 3.7114 & .84652 \\
\hline Packaging & 1.67 & 3.67 & 2.6806 & .49521 \\
\hline & & \multicolumn{3}{|c}{ Source: The Authors }
\end{tabular}


Table 4 Correlation matrix for analysed indicators

\begin{tabular}{l|c|c|c|c|c|c|c|c}
\hline \multicolumn{1}{c|}{ Indicators } & $\begin{array}{c}\text { Quality } \\
\text { label }\end{array}$ & $\begin{array}{c}\text { Product } \\
\text { origin }\end{array}$ & $\begin{array}{c}\text { Composition of } \\
\text { raw materials }\end{array}$ & $\begin{array}{c}\text { Freshne } \\
\text { ss }\end{array}$ & Price & Taste & Place of sale & Packaging \\
\hline Quality label & 1 & & & & & & & \\
\hline Product origin & $.753^{* *}$ & 1 & & & & & & \\
\hline $\begin{array}{l}\text { Composition of raw } \\
\text { materials }\end{array}$ & $.873^{* *}$ & $.908^{* *}$ & 1 & & & & & \\
\hline Freshness & $.561^{* *}$ & $.571^{* *}$ & $.849^{* *}$ & 1 & & & & \\
\hline Price & $-.247^{* *}$ & $-.702^{* *}$ & $-.495^{* *}$ & $.388^{* *}$ & 1 & & & \\
\hline Taste & .415 & .323 & .267 & .258 & .316 & 1 & & \\
\hline Place of sale & $.471^{* *}$ & $.894^{* *}$ & $.316^{* *}$ & $.461^{* *}$ & $.656^{* *}$ & .406 & 1 & \\
\hline Packaging & .138 & .735 & .401 & .443 & .567 & .373 & .482 & 1 \\
\hline$*$ Correlation is significant at the level 0.01 & & & & & & Source: The Authors
\end{tabular}

In the given matrix, we note that the greatest deviations, i.e. the largest number of statistically significant differences, are indicated by indicators of Quality label, Composition of raw materials and Product origin. Observed individually in relation to each other, the highest coefficient of correlation is marked with Quality label and Composition of raw materials $(\mathrm{r}=0.873)$, Product origin and Composition of raw materials $(\mathrm{r}=0.908)$ and Composition of raw materials and Freshness $(\mathrm{r}=0.849)$. This means that if consumers are satisfied with the quality label, composition of raw materials and product origin, they will probably choose to buy that organic product. There is also a significant correlation between price indicators and other variables, however, with a negative sign. Deviations are not recorded for indicators Taste and Packaging.

In order to test hypotheses and to examine the influence and correlation of the indicated group of indicators on the decision to purchase food products of organic origin, a multiple regression analysis was applied. The Enter method, which includes all independent variables to predict the dependent variable, has shown that the regression model is statistically significant $(\mathrm{F}(500 ; 7)=2.68$, $\mathrm{p}<0.001)$. In other words, a set of tested indicators statistically significantly predicts the decision to purchase of organic food in the AP Vojvodina market. It describes $67.8 \%$ of the variance of the criteria. In addition to the overall contribution of the set of indicators, the contribution of individual indicators was also examined (Table 5).
Table 5 Individual contribution of the indicator to the explanation of the dependent variable

\begin{tabular}{l|c|c|c|c}
\hline \multirow{2}{*}{ Model } & \multicolumn{2}{|c|}{$\begin{array}{c}\text { Standardized } \\
\text { coefficient }\end{array}$} & \multirow{2}{*}{$\mathbf{t}$} & \multirow{2}{*}{ Sig. } \\
\cline { 2 - 4 } & Beta & $\begin{array}{c}\text { St. } \\
\text { error }\end{array}$ & & \\
\hline (constant) & 1.22 & 1.472 & 2.476 & .000 \\
\hline Quality label & $.422^{* *}$ & .252 & .306 & .000 \\
\hline Product origin & $.212^{* *}$ & .587 & 1.001 & .000 \\
\hline $\begin{array}{l}\text { Composition of } \\
\text { raw materials }\end{array}$ & $.747^{* *}$ & .172 & .388 & .001 \\
\hline Freshness & $-.091^{*}$ & .591 & 1.282 & .003 \\
\hline Price & $-.726^{* *}$ & .450 & .060 & .000 \\
\hline Taste & .202 & .698 & 1.362 & .057 \\
\hline Place of sale & $.573^{*}$ & .281 & .295 & .003 \\
\hline Packaging & .181 & .583 & .842 & .124 \\
\hline
\end{tabular}

** Significant at the level 0,01

* Significant at the level 0,05

Based on the presented data, it is noticeable that the decision to purchase food products of organic origin is statistically significantly predicted by Quality labels $(B=0.422)$, Composition of raw materials $(B=0.747)$ and Product origin $(0.212)$, while contribution of Price is also statistically significant but in a negative direction $(B=-0.726)$. This analysis has confirmed research hypotheses $\mathbf{H}_{1}, \mathbf{H}_{2}, \mathbf{H}_{3}$ and $\mathbf{H}_{5}$ which means that any change in these indicators statistically significantly affects consumers' decision on the selection and purchase of food products of organic origin on the market of AP Vojvodina. This correlation is positive in the case of Quality label, Product origin and Composition of raw materials, i.e. with a significant increase in the impact of these indicators, consumers are more determined to buy organic products, while the negative sign in Price means that the volume of organic food sales decreases with its growth. This result coincides with the results of related studies (Vehapi, 2015). Research hypotheses $\mathbf{H}_{4}$ and $\mathbf{H}_{7}$ are on the border of statistical significance, i.e. Freshness $(B=-0.91)$ 
and Place of sale $(B=0.573)$ moderately affect the selection of food products of organic origin. Remaining research hypotheses $\mathbf{H}_{6}$ and $\mathbf{H}_{8}$ are not accepted because the indicators Taste $(B=0.202)$ and Packaging $(\mathrm{B}=0.181)$ did not make a statistically significant contribution.

\section{Discussion}

The obtained results and the conducted tests indicate that final consumers from the AP Vojvodina market show a different level of interest in certain indicators when they make a decision on the purchase of organic products. They express a clear need for Quality label to be transparently emphasized, to check Composition of raw materials and Product origin, while they adversely react to high prices by withdrawing from purchase. In this context, based on the statistical significance in the previous table, it is possible to present the regression model (equation), which points to the individual significance of the analysed indicators on the placement of food products of organic origin on the market of AP Vojvodina (1).

$$
\begin{gathered}
y=1.22+0.422 x_{1}+0.212 x_{2}+0.747 x_{3}-0.091 x_{4}- \\
0.726 x_{5}+0.573 x_{6}
\end{gathered}
$$

In the given equation, $y$ represents the placement of food products of organic origin, while $x$ marks independent indicators, such as: $x_{1}$ - quality label, $x_{2}$ - product origin, $x_{3}$ - composition of raw materials, $x_{4}-$ freshness, $x_{5}-$ price and $x_{6}-$ place of sale. Indicators that do not have a statistically significant contribution are not included in the regression model.

A defined regression model, for the purpose of a clearer interpretation, can be graphically presented in the following way.

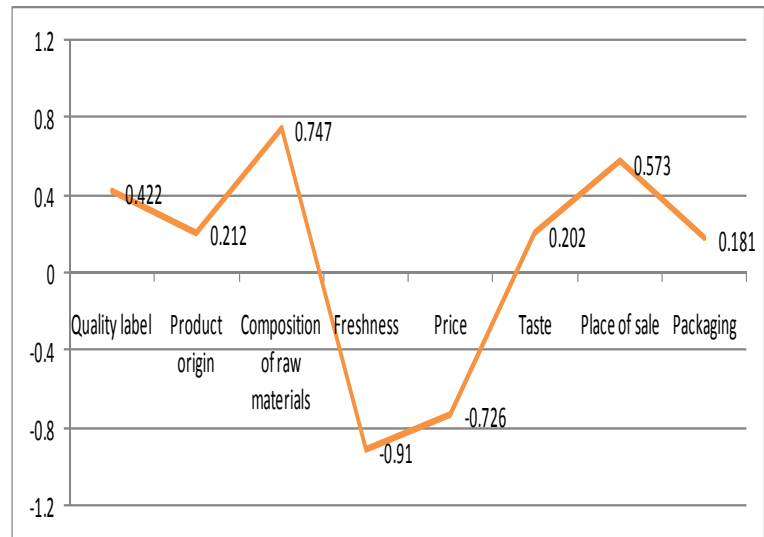

Figure 1 Placement of food products of organic origin Source: The Authors.

The presented model points to indicators that supply chain managers need to optimize and develop in order to adjust the placement of organic food products to the needs and expectations of end consumers in the AP Vojvodina market. This implies that all participants in the supply chain must certify and standardize their production and service processes and through transparent labels and quality certificates clearly differentiate organic from inorganic alternatives in our market. The European Commission (EC) by its Directive 2000/13/EC unequivocally supports and encourages the introduction and protection of regional quality and origin labels. In our legislative system this area is regulated by the Law on Indications of Geographical Origin.

In addition to the quality label, a declaration must be marked on the packaging or the product itself, which confirms the organic composition of the product without additional flavour, colour, sweetener, emulsifier, etc. Furthermore, in the specification accompanying the product, manufacturers must guarantee the use of pesticides in fruits and vegetables, the method of feeding animals for meat and meat products, milk and milk products, etc.

The biggest challenge for the participants in the supply chain in the AP Vojvodina market is the price that has been indicated in several studies as one of the main limiting factors in the purchase of organic products in the regional market (Vehapi, 2015; Brčić-Stipčević et al, 2011). The organic production market, especially in the Republic of Serbia, is still underdeveloped and there is not enough large volume of consumption that could justify large investments in expensive technology, land, modes of transport, storage and placement of food products of organic origin. Their price is now about $30 \%$ higher than of conventional products, and therefore it is a challenge for manufacturers, farmers and trading companies to try to minimize unnecessary costs of change of ownership, storage and physical distribution through vertical integration and collaboration, in order to reduce the price of these products. The assumption is that it would amount to a maximum of $10 \%$ above the price of non-organic alternatives and thus make organic food more accessible to a growing number of consumers (Končar et al, 2018). Besides, many studies confirm that organic production can be next interesting an attractive placement for employment and growth of self-employment (Nica, 2018; Koppel \& Kolencik, 2018).

A somewhat less importance is given to freshness and the place where food products are sold, although participants in the supply chain 
should not neglect more efficient promotion of organic food, investments in modern packaging and packaging systems, improvement of taste through higher content of vitamins, nutrients, etc. Although these indicators do not currently have a statistically significant contribution, studies show that in the near future, larger investments in promotion, packaging and taste, along with all previously fulfilled indicators, will clearly differentiate food products of organic origin in our market.

\section{Conclusion}

The market of organic products, especially food products of organic origin, is constantly increasing. More and more participants in the supply chain are redirecting their production and service processes towards organic technology. As a result of such tendencies, demand for organic food is increasing. Hence, there is a need for researching the retail sector of food products of organic origin, due to the growing importance of this sector in the overall economic development of AP Vojvodina.

The obtained results showed that the final consumers, when choosing and purchasing food products, mostly appreciate Quality labels, Composition of raw materials, Price, Product origin, Freshness and Place of sale. Statistical tests have determined significant contributions of these indicators to the decision to purchase food products of organic origin. In other words, the conclusion of the research is that with the growth of these indicators, consumers show greater readiness to purchase organic products, except for the price where there is a negative correlation.

Growth in organic food prices is redirecting final consumers to purchasing alternative products from conventional processing.

The practical significance of the research is reflected in the fact that the presented results unambiguously show to the supply chain management and all participants, in which indicators it is necessary to invest and to what extent they need to be developed and optimized in order to make the placement of food products of organic origin more efficient, economical and profitable in the AP Vojvodina market.

The lack of research is the territorial limitation on the market of AP Vojvodina, exclusively as a result of the authors' knowledge of the structure of placements in the domicile market. This would result in suggestions for future research that should include a wider market segment (e.g. Western Balkans, South-eastern Europe), comparative analysis between EU and non-EU countries, analysis and influence of subindicators within the tested groups, etc.sm

\section{References}

Arsi, K., Donoghue, D. J., Venkitanarayanan, K., \& Donoghue, A. M. (2019). Reducing Foodborne Pathogens in Organic Poultry: Challenges and Opportunities. In K. Venkitanarayanan, S. Thakur \& S. C. Ricke (Eds.). Food Safety in Poultry Meat Production (pp. 25-46). Cham: Springer.

Brčić-Stipčević, V., Petljak, K., \& Guszak, I. (2011). Kanali distribucije i obilježja tržišta ekoloških prehrambenih proizvoda. Proceedings of XI. international scientific conference" Business Logistics in Modern Management" (pp. 111-125). University of Osijek, Faculty of Economics and Business, Osijek, Croatia.

Batte, M. T., Hooker, N. H., Haab, T. C., \& Beaverson, J. (2007). Putting their money where their mouths are: Consumer willingness to pay for multi-ingredient, processed organic food products. Food policy, 32(2), 145-159. https://doi.org/10.1016/j.foodpol.2006.05.003

Charter, M. (2001). Integrated product policy (IPP) and ecoproduct development (EPD), In Environmentally Conscious Design and Inverse Manufacturing, 2001. Proceedings EcoDesign 2001: Second International Symposium (pp. 672-677).

Gulan, B. (2017). Organska proizvodnja hrane u Srbiji 2017. Makroekonomija. Retrieved March 11, 2019 from: https://www.makroekonomija.org/0-branislavgulan/organska-proizvodnja-hrane-u-srbiji-2017/.

Gebhardt, B., \& Heinz, L. (2018). Wirbt Bio anders? Inhaltsanalytischer Vergleich von Printanzeigen für BioLebensmittel und konventionelle Lebensmittel. 15.Wissenschaftstagung Ökologischer Landbau Beitrag.

Grubor, A., \& Đokić, N. (2015). Determinants of choice of global and national food products' brands. Strategic Management, 20(2), 58-67.

Hjelmar, U. (2011). Consumers' purchase of organic food products. A matter of convenience and reflexive practices. Appetite, 56(2), 336-344. https://doi.org/10.1016/j.appet.2010.12.019

Honkanen, P., Verplanken, B., \& Olsen, S. O. (2006). Ethical values and motives driving organic food choice. Journal of Consumer Behaviour: An International Research Review, 5(5), 420-430. https://doi.org/10.1002/cb.190

Wier, M., Jensen, K. O. D., Andersen, L. M., \& Millock, K. (2008). The character of demand in mature organic food markets: Great Britain and Denmark compared. Food Policy, 33(5), 406-421. https://doi.org/10.1016/j.foodpol.2008.01.002.

Jurjević, Ž., Bogićević, I., Đokić, D, \& Matkovski, B. (2019). Information Technology as aFactor of Sustainable Development of Serbian Agriculture. Strategic Management, 24(1), 41-46. https://doi.org/10.5937/StraMan1901041J

Končar, J., Marić, R., \& Vukmirović, G. (2018). Challenges of vertical integration of supply chains' members of food and organic products with domestic origin. Anali Ekonomskog fakulteta u Subotici, 54(40), 149-169. https://doi.org/10.5937/AnEkSub1840149K 
Končar, J., Grubor, A., Marić, R., Vukmirović, G., \& Đokić, N. (2019). Possibilities to improve the image of food and organic products on the AP Vojvodina market by introducing a regional quality label. Food and Feed Research, 46(1). 111-124. https://doi.org/10.5937/FFR1901111K

Kocić, M, Marinković, V, \& Alimpic, S. (2016). Merenje vrednosti Brenda za potrošače: Empirijski dokazi sa tržišta prehrambenih proizvoda u Srbiji. Anali Ekonomskog fakulteta u Subotici, 52(35), 189-206.

Koppel, J., \& Kolencik, J. (2018). The future of workers: Contingent forms of labor contracting in the platform economy. Psychosociological Issues in Human Resource Management, 6(1), 172-177. Retrieved March 11, 2019 from: https://www.ceeol.com/search/article-detail?id=665240.

Kihlberg, I., \& Risvik, E. (2007). Consumers of organic foods-value segments and liking of bread. Food quality and preference, 18(3), 471-481. https://doi.org/10.1016/j.foodqual.2006.03.023

Kataria, Y. S., Krishna, H. G., Tyagi, V. K., \& Vashishat, T. (2019). Consumer Buying behavior of Organic food Products in India Through the Lens of Planned Behavior Theory. Research Journal of Humanities and Social Sciences, $10(1), 60-67$ https://doi.org/0.5958/2321-5828.2019.00011.1

Koklic, M. K., Golob, U., Podnar, K., \& Zabkar, V. (2019). The interplay of past consumption, attitudes and personal norms in organic food buying. Appetite, 137, $27-34$. https://doi.org/10.1016/j.appet.2019.02.010

Martić Kuran, L., \& Mihić, M. (2014). Primjena teorije planiranog ponašanja u kupovini ekološke hrane. Market-Tržište, 26 (2), 179-197. https://doi.org/0000-0003-0234-941X

Nica, E. (2018). Gig-based working arrangements: Business patterns, labor-management practices, and regulations. Economics, Management, and Financial Markets, 13 (1), 100-105. Retrieved March 11, 2019 from: https://www.ceeol.com/search/articledetail $\mathrm{id}=638336$

Nguyen, H. V., Nguyen, N., Nguyen, B. K., Lobo, A., \& Vu, P. A. (2019). Organic Food Purchases in an Emerging Market: The Influence of Consumers' Personal Factors and Green Marketing Practices of Food Stores. International journal of environmental research and public health, 16 (6), 1037-1047. https://doi.org/10.3390/ijerph16061037
Pearson, D., Henryks, J., Sultan, P., \& Anisimova, T. (2013). Organic food: Exploring purchase frequency to explain consumer behavior. Journal of Organic Systems, 8 (2), 50-63. Retrieved from: https://www.researchgate.net/profile/Joanna Henryks/p ublication/261474774 Organic Food Consumers Expl oring Purchase Frequency to Explain the AttitudeBehaviour Gap/links/0deec53461ea8ce1e9000000.pdf

Popescu, G. H. (2018). Participation in the sharing economy: Labor, exchange, and consumption. An empirical analysis. Journal of Self-Governance and Management Economics, 6 (1), 122-127. Retrieved March 11, 2019 from: https://www.ceeol.com/search/article-detail?id=642535.

Prodanović, R., Kuzman, B., Jovović, D., \& Ozegović, L. (2017). Market and trade of organic fruits in Serbia. Economics of Agriculture, 64 (1), 141-155. https://doi.org/10.5937/ekoPolj1701141P

Sponte, M. (2018). Cognitive Performance and Labor Market Outcomes: Evidence from the Us. Economics, Management, and Financial Markets, 13 (2), 70-75. Retrieved March 11, 2019 from: https://www.ceeol.com/search/article-detail?id=676866.

Stojanović, Ž., \& Ognjanov, G. (2012). Strateška opredeljenja Srbije u domenu ruralnog razvojaproizvodnja i marketing tradicionalne hrane. Economic Themes, 50, 19-32.

Vlahović, B., Puškarić, A., \& Jeločnik, M. (2011). Consumer Attitude to Organic Food Consumption in Serbia. Bulletin: Economic Sciences Series, 43, 45-52.

Retrieved March 11, 2019 from: http://www.upg-bulletinse.ro/archive/20111/6.\%20Vlahovic_Puskaric_Jelocnik.pdf.

Vehapi, S. (2015). Istraživanje motiva potrošača koji utiču na kupovinu organske hrane u Srbiji. Ekonomske teme, 53 (1), 105-1021. Retrieved March 11, 2019 from: http://економске-теме.срб/pdf/et20151_07.pdf.

Truong, T. T., Yap, M. H., \& Ineson, E. M. (2012). Potential Vietnamese consumers' perceptions of organic foods. British Food Journal, 114 (4), 529-543. https://doi.org/10.1108/00070701211219540

Wong, W. M., \& Tzeng, S. Y. (2019). Consumers'psychographics and green consumption intention: community supported agriculture business model in China. International Journal of Business \& Society, 20 (1), 229-246.

\section{$\triangle$ Correspondence}

\section{Radenko Marić}

University of Novi Sad, Faculty of Economics in Subotica Segedinski put 9-11, 24000, Subotica, Serbia

E-mail: radenko.maric@ef.uns.ac.rs 